\title{
Strategi Komisi Pemilihan Umum Provinsi Sumatera Utara Dalam Meningkatkan Partisipasi Masyarakat Pada Pemilihan Gubernur Sumatera Utara 2018
}

\section{Strategy of the General Election Commission of North Sumatra Province in Increasing Community Participation in the Election of the Governor of North Sumatra 2018}

\author{
Sri Juniarti Hasibuan'), Abdul Kadir ${ }^{2)}$ \& Muhammad Husni Thamrin Nasution 2)* \\ 1) Program Studi Ilmu Pemerintahan, Fakultas Ilmu Sosial dan Ilmu Politik \\ Universitas Medan Area, Indonesia \\ 2) Program Studi Administrasi Publik, Fakultas Ilmu Sosial dan Ilmu Politik \\ Universitas Medan Area, Indonesia
}

Diterima: Mei 2019; Disetujui: Mei 2019; Dipublish: Juni 2019

\begin{abstract}
Abstrak
Partisipasi masyarakat pada saat Pemilihan Gubernur Sumatera Utara merupakan suatu aspek yang sangat penting sehingga Komisi Pemilihan Umum menggunakan strategi khusus untuk meningkatkan partisipasi masyarakat pada Pemilihan Gubernur Sumatera Utara. Sifat pada penelitian ini adalah deskriptif. Hasil penelitian menunjukkan bahwa strategi Komisi Pemilihan umum Provinsi Sumatera Utara dalam meningkatkan partisipasi masyarakat pada pemilihan Gubernur Sumatera Utara 2018 dilihat dari tiga tahapan yaitu tahapan formulasi menunjukkan adanya kejelasan perencanaan, kedua tahapan pemilihan tindakan dengan menunjukkan pelaksanaan sosialisasi kepada segmen pemilih dengan metode sosialisasinya ketiga tahap alokasi sumber daya yaitu dengan melakukan bimbingan teknis kepada panitia. Adapun kendala yang dialami Komisi Pemilihan Umum Provinsi Sumatera Utara yaitu terletak pada alokasi sumberdaya manusia yang sangat terbatas di daerah.
\end{abstract}

Kata Kunci: Partisipasi Masyarakat, Pilkada, Strategi

\section{Abstract}

Community participation at the time of the North Sumatera Governor Election is a very important aspect so that the General Election Commission uses a special strategy to increase public participation in the Gubernur Pemilihan of North Sumatera. The nature of this research is descrptive. The result of the research shows that the strategy of North Sumatera Provincial Election Commission in increasing the society participation in Sumatera Governor Election 2018 is seen from three stages namely the formulation stage shows there is clarity of socialization plan. The stage of action selection shows the implementation of sosialization to the voters segment with the methode of socialization third stage of resource allocation namely by doing technical guidance to the committee. The constraints experienced by the Election Commission of North Sumatera Province is located on the allocation of human resources is very limited in the region.

Keyword : Participation Community, Pilkada, Strategy

How to Cite: Hasibuan, S.J. Kadir, A. \& Nasution, M.H.T. (2018). Strategi Komisi Pemilihan Umum Provinsi Sumatera Utara Dalam Meningkatkan Partisipasi Masyarakat Pada Pemilihan Gubernur Sumatera Utara 2018. PERSPEKTIF, 7 (1): 1-5. 


\section{PENDAHULUAN}

Pemilihan umum (Pemilu) merupakan sarana kedaulatan rakyat sekaligus perwujudan demokrasi. Gelombang demokrasi yang melanda hampir setiap negara dibelahan bumi termasuk di Indonesia telah membawa perubahan dalam tatanan politik Indonesia. Pemilihan Kepala Daerah memang merupakan peluang sekaligus tantangan bagi bangsa Indonesia pada umumnya dan bagi daerahdaerah khusus nya dalam meningkatkan demokratisasi di atas tanah air.

Bagi masyarakat, pilkada adalah peluang emas untuk menentukan sendiri tokoh-tokoh yang dianggap pantas, mampu dan layak menjadi Gubernur, Bupati maupun Walikota.

Kerterlibatan masyarakat dalam konstelasi pilkada menuntut adanya partisipasi dari masyarakat. Partisipasi yang tinggi dari masyarakat dalam pilkada juga mengisyaratkan kelegitimasian calon kepala daerah tersebut. Partisipasi masyarakat dalam pemilihan umum juga dapat menjadi bukti kedewasan kita dalam berdemokrasi.

Berdasarkan Undang-Undang No. 15 Tahun 2011 tentang Penyelenggaraan Pemilu menyebutkan bahwa "untuk meningkatkan penyelenggaraan pemilihan umum yang dapat menjamin pelaksanaan hak politik masyarakat dibutuhkan pemilihan umum yang professional, serta mempunyai integritas, kapabilitas dan akuntabilitas melalui Komisi Pemilihan Umum, sehingga dalam implementasinya dapat mewujudkan partisipasi masyarakat untuk mendukung terlaksananya pemilihan umum yang bersih, jujur dan adil sesuai dengan spirit demokrasi dan kearifan local di Indonesia".

Secara umum dapat digambarkan peran Komisi Pemilihan Umum yakni mengadakan sosialisasi, fungsionalisasi institusi pemerintahan secara proporsional, mampu membangun kerja sama dan koordinasi yang harmonis dengan desk pemilu dan konsisten dalam pelaksanaan regulasi sehingga Komisi Pemilihan Umum dapat menempatkan dirinya secara netral.Sumatera Utara yang akan melaksanakan pesta demokrasi pada tanggal 27 Juni 2018.

Dimana ada sekitar 10.295.013 jiwa pemilih di Provinsi ini, dimana sebanyak 5.09.149 jiwa berjenis kelamin laki-laki dan 5.203.864 jiwa berjenis kelamin perempuan. (https://www.tagar.id/kpu-sumut-tetapkan-- 9052529--dpt-pilgubsu-2018, di akses pada tanggal 21 April 2018). Pilkada ini di ikuti dua pasangan calon yakni Edy Rahmayadi beserta wakilnya Musa Rajeksa dan Djarot Syaifullah beserta wakilnya Sihar Sitorus.

Strategi merupakan sebuah langkah yang dilakukan oleh individu atau organisasi dalam proses pencapaian tujuannya dengan mengambil langkah-langkah seperti menentukan tujuan dan sasaran jangka panjang, penggunaan serangkaian tindakan serta pengalokasian sumber daya yang diperlukan untuk mencapai tujuan tersebut, Chandler (dalam Salusu 2015). Dari ketiga langkah pelaksanaan strategi tersebut bila dilaksanakan dengan baik maka akan dapat mencapai hasil yang maksimal. Komisi Pemilihan Umum dalam meningkatkan partisipasi masyarakat pada Pemilukada, Strategi yang digunakan yaitu dengan melakukan sosialisasi pemilukada kepada masyarakat.

Partisipasi masyarakat merupakan implementasi kedaulatan rakyat yang dimanifestasikan oleh keterlibatan pemilih dalam pesta demokrasi (Kusmanto, 2013). Semakin tinggi partisipasi menandakan bahwa rakyat mengikuti, memahami, dan melibatkan diri dalam kegiatan kenegaraan (Suharyanto, 2014). Rendahnya tingkat partisipasi politik rakyat direfleksikan dalam sikap golongan putih dalam pemilu (Kusmanto, 2014).

Sebagian masyarakat masih melihat pemilu sebagai ajang pencapaian kekuasaan semata dan tak memberi manfaat untuk perbaikan ke depan. Sebagian menilai para calon anggota legislatif suku mengumbar janji yang tidak dipenuhi. Akibatnya, pada pelaksanaan pemilu, masyarakat kurang peduli karena menganggap proses pemilu hanya buang-buang waktu dan tidak mempunyai manfaat.

\section{METODE PENELITIAN}

Dalam penelitian ini, penulis menggunakan pendekatan kualitatif. Menurut (Sugiyono, 2014) bahwa: Metode penelitian kualitatif adalah metode penelitian yang berlandaskan pada filsafat postpositivisme, digunakan untuk meneliti pada kondisi obyek yang alamiah, (sebagai lawannya adalah eksperimen) dimana peneliti adalah sebagai intrumen kunci, teknik pengumpulan data dilakukan secara triangulasi (gabungan), 
analisis data bersifat induktif/kualitatif, dan hasil penelitian kualitatif lebih menekankan makna dari pada generalisasi.

Lokasi penelitian dilakukan pada Kantor Komisi Pemilihan Umum Provinsi Sumatera Utara, yang beralamat di jalan Perintis Kemerdekaan No. 35 Medan. Penelitian ini dilaksanakan dengan mengumpulkan data melalui Observasi, Wawancara kepada Ketua KPU Provinsi Sumatera Utara, Komisioner KPU Provinsi Sumatera Utara Divisi SDM dan Masyarakat Kota Medan, Dokumentasi dan Triangulasi. Waktu penelitian ini dilaksanakan pada bulan April.

Untuk memperoleh data dari lapangan, peneliti menggunakan beberapa metode pengumpulan data sesuai dengan jenis penelitian, adapun metode pengumpulan data sebagai berikut: Pengamatan/Observasi sebagai metode ilmiah observasi dapat diartikan sebagai pengamatan, meliputi pemusatan perhatian terhadap suatu obyek dengan menggunakan seluruh alat indra.

Esterberg (dalam Sugiyono, 2008) mendefenisikan wawancara adalah pertemuan dua orang untuk bertukar informasi dan ide melalui tanya jawab, sehingga dapat dikonstruksikan makna dalam suatu topik tertentu.

Dokumentasi adalah salah satu pengumpulan data dengan cara melakukan analisis terhadap semua catatan dan dokumen yang dimiliki oleh organisasi yang terpilih sebagai objek penelitian, atau data dari individu sebagai objek penelitian.

Dalam hal triangulasi, Susan Stainback (Sugiyono, 2008) menyatakan bahwa tujuan triangulasi bukan untuk mencari kebenaran tentang beberapa fenomena, tetapi lebih pada peningkatan pemahaman peneliti terhadap apa yang telah ditemukan.

Analisa data dalam penelitian kualitatif, dilakukan pada saat pengumpulan data berlangsung, dan setelah selesai pengumpulan data dalam periode tertentu. Pada saat wawancara, peneliti sudah melakukan analisis terhadap jawaban yang diwawancarai. Bila jawaban yang diwawancarai setelah dianalisis terasa belum memuaskan, maka peneliti akan melanjutkan pertanyaan lagi, sampai tahap tertentu, diperoleh data yang dianggap kredibel.
Miles dan Huberman (Sugiyono, 2008), mengemukakan bahwa aktivitas dalam analisis data kualitatif dilakukan secara interaktif dan berlangsung secara terus menerus sampai tuntas, sehingga datanya sudah jenuh. Aktivitas dalam analisis data, yaitu Reduksi data, penyajian data dan penarikan kesimpulan/verifikasi.

\section{HASIL DAN PEMBAHASAN}

KPU Provinsi dibentuk berlandaskan dari ketentuan UU No. 15 Tahun 2011 pasal 3 tentang wilayah kerja KPU, pasal 4 ayat 2 tentang kedudukan KPU Provinsi serta pasal 6 tentang jumlah anggota KPU Provinsi dan tidak mengubah pembagian tugas, fungsi, wewenang dan kewajiban anggota KPU dalam merencanakan dan melaksanakan tahaptahap, jadwal dan mekanisme Pemilu DPR, DPD, DPRD, Pemilu Presiden/Wakil Presiden dan Pemilu Kepala Daerah dan Wakil Kepala Daerah. Penyelenggaran Pemilu KPU berpedoman kepada asas mandiri, jujur, adil, kepastian hukum, tertib penyelenggara Pemilu, kepentingan umum, dan keterbukaan. Beranjak dari keputusan Presiden No. 16 Tahun 1999 dan dengan diundangkannya undang-undang penyelenggara pemilu maka terbentuklah Komisi Pemilihan Umum Provinsi meliputi KPU Provinsi Sumatera Utara. (selanjutnya lihat UU No. 15 Pasal 3 Ayat 1 tentang wilayah kerja KPU, pasal 4 ayat 2 tentang kedudukan KPU Provinsi berdasarkan wilayah kerja dan pasal 6 tentang keanggotan KPU Provinsi)

Berdasarkan Undang-Undang Nomor 15 Tahun 2011 tentang Penyelenggara Pemilihan Umum dijelaskan bahwa untuk melaksanakan Pemilihan Umum dijelaskan bahwa untuk melaksanakan Pemilihan Umum KPU Provinsi mempunyai tugas, wewenang serta kewajiban sebagai berikut: a) Menjabarkan program dan melaksanakan anggaran serta menetapkan jadwal Pemilu di Provinsi; b) Melaksanakan semua tahapan penyelenggaran Pemilu di Provinsi berdasarkan ketentuan peraturan perundang-undangan; c) Mengkoordinasikan, menyelenggarakan dan mengendalikan tahapan penyelenggraan Pemilu oleh KPU Kabupaten/Kota; d) Menerima daftar pemilih dari KPU Kabupaten/Kota dan menyampaikannya kepada KPU. 
Berdasarkan tujuan dari penelitian maka untuk mengetahui strategi Komisi Pemilihan Umum Provinsi sumatera Utara dalam meningkatkan partisipasi masyarakat pada Pemilihan Gubernur Sumatera Utara 2018 di Kota Medan dapat dilihat dari beberapa aspek Strategi.

Hasil Wawancara Berdasarkan Indikator Dalam Formulasi dan Sasaran Jangka Panjang KPU dalam Meningkat Partisipasi Masyarakat, Menunjukkan ada kejelasan perencanaan sosialisasi dari KPU Pendidikan Politik, melalui penjaringan sosial, pembentukan relawan demokrasi kepemiluan.

Hasil Wawancara Berdasarkan Indikator Pemilihan Tindakan: KPU Melaksanakan Sosialisasi Kepada Sekmen Pemilih Dengan Metode Sosialisasinya yaitu berupa tatap muka serta penggunaan media massa dengan Pola Pelaksanaanya. paling efektif itu adalah forum warga dan warga netizen. Pertama forum warga itu langsung ke basis, langsung ke masyarakat jadi sosialisasi itu melibatkan kepala keluarga karena mereka adalah masyarakat terkecil di negara kita itu menjadi efektif untuk disosialisasikan ke keluarganya yang kemudian berkembang ke sekitarnya.

Hasil Wawancara Berdasarkan Indikator Alokasi Sumber Daya KPU Melakukan Bimbingan Teknis Kepada Panitia.

Dalam perencanan strategis, alokasi sumber daya adalah suatu rencana untuk menggunakan sumber daya yang tersedia, contonya sumber daya manusia, khususnya dalam jangka waktu dekat untuk merai tujuan masa depan. Dalam hal ini KPU juga harus memiliki sumber daya yang dapat dialokasikan untuk mencapai tujuan KPU itu sendiri.

\section{SIMPULAN}

Berdasarkan hasil dan pembahasan penelitian diatas, penulis dapat melihat bahwa Strategi Komisi Pemilihan Umum Provinsi Sumatera Utara dalam meningkatkan partispasi masyarakat pada Pemilihan Gubernur Sumatera Utara Tahun 2018 sangatlah tersistem dan variatif. Dapat dilihat dari formulasi dan sasaran jangka panjang, KPU Provinsi Sumatera Utara sudah memiliki rencana sendiri dengan melaksanakan program-program yang sangat bervariasi yang bertujuan untuk menyentuh lapisan masyarakat. Inovasi terkait program juga dilakukan KPU dalam upaya meningkatkan persentase pemilih di Provinsi Sumatera Utara. Dari segi hambatan sendiri terletak pada alokasi sumber daya manusia yang menurut KPU sangat terbatas terlebih didaerah. Hal ini tentu menghambat kinerja KPU dan juga mengenai dana juga menjadi masalah di KPU.

\section{DAFTAR PUSTAKA}

Achmadi dan Narkubo. (2004). Metode Penelitian. Jakarta. Bumi aksara

Alfian. (1992). Sosiologi Politik. Jakarta. Rajawali

Kantaprawira, R. (2004). Sistem Politik Indonesia Suatu Model Pengantar. Bandung. Sinar Baru Argensindo.

Komaruddin. (2005). Persoalan Pembangunan Ekonomi Indonesia. Bandung. Bandung Alumni.

Kusmanto, H., (2013). Peran Badan Permusyawaratan Daerah dalam Meningkatkan Partisipasi Politik Masyarakat, Jurnal Ilmu Pemerintahan dan Sosial Politik UMA, 1 (1): 41-47.

Kusmanto, H, (2014). Partisipasi Masyarakat dalam Demokasi Politik, Jurnal Ilmu Pemerintahan dan Sosial Politik UMA, 2 (1): 77-89

Manik, K.H. dkk. (2014). Partisipasi Pemilih dalam Pemilu 2014. Jakarta.

Maran. (2007). Pengantar Sosiologi Politik. Jakarta. Asdi Mahasatya.

Moleong, J,L. (2006). Metode Penelitian Kualitatif. Bandung. PT Remaja Rosdakarya.

Rahmat, M.H. (2015). Pilkada. Jakarta. Pilkada Serentak.

Arifin, R. (2002). Sistem Politik Indonesia. Surabaya.

Rush, M, Dan Althoff, P. (2001). Pengantar Sosiologi Politik. Jakarta. PT Raja Grafindo Persada.

Salusu. (2006). Pengambilan Keputusan Stratejik Untuk Organisasi Publik Dan Organisasi Nonprofit. Jakarta. PT Gramedia Widiasarana Indonesia.

Salusu. (2015). Pengambilan Keputusan Stratejik Untuk Organisasi Publik Dan Organisasi Nonprofit. Jakarta. PT Gramedia Widiasarana Indonesia.

Sugiyono. (2005). Metode Penelitian Administrasi. Bandung. Alfabeta - (2008). Metode Penelitian Pendidikan Pendekatan Kuantitatif dan Kualitatif Dan $R \& D$. Bandung. Alfabeta , (2014). Metode Penelitian Kualitatif Dan $R \& D$. Bandung. Alfabeta ' (2015). Metode Penelitian Pendidikan Pendekatan Kuantitatif dan Kualitatif Dan R\&D. Bandung. Alfabeta.

Suharyanto, A., (2014). Partisipasi Politik Masyarakat Tionghoa dalam Pemilihan Kepala Daerah, Jurnal Ilmu Pemerintahan dan Sosial Politik UMA, 2 (2): 166-175 
Supriyono, A. (2014). Mendorong Partisipasi Masyarakat Dalam Pemilu. Jakarta Selatan. Perludem.

UU No. 15 Tahun 2011 tentang Penyelenggaraan Pemilu

Haryono, D. (2016). "Strategi KPU dalam meningkatkan partisipasi pemilih pada pemilihan Walikota dan Wakil Walikota Samarinda tahun 2015" Journal Administrative Reform, Vol.4.No.2. Diakses pada tanggal 13 November 2017 pada pukul 10.00 WIB. (https://news.detik.com/berita/2195547/tingkatgolput-dalam-pilgub-sumut-lebih-dari-50persen) Diakses pada 15 maret 2013 pada pukul 10.00 WIB

(http://www.kpu.go.id/index.php/pages/detail/20 14/8/PEMILU-1955/MzQz) Diakses 30 April 2018 pada pukul 15.00 WIB)

(http://portal.mahkamahkonstitusi.go.id/eLaw/mg 58ufsc89hrsg/KEPPRES_67_2002_ok.pdf)Dia kses 30 April 2018 pada pukul 13.00 WIB. 